\title{
Nessia gansi: a Second Three-toed Snake-Skink (Reptilia: Squamata: Scincidae) from Sri Lanka with the Designation of a Neotype for Nessia burtonii Gray
}

\author{
Sudesh BATUWITA ${ }^{1,2, *}$, Udeni EDIRISINGHE ${ }^{2}$ \\ ${ }^{1}$ The Society for the Biodiversity Conservation, 63/4, Adikaramwatta, Yaggahapitiya, Gunnepana \\ 20270, Sri Lanka. \\ ${ }^{2}$ Postgraduate Institute of Agriculture, University of Peradeniya, Sri Lanka (Present address: College \\ of Biology and the Environment, Nanjing Forestry University, Nanjing, China). \\ *corresponding author, e-mail: sbatuwita@pgia.ac.lk,sudesh.batuwita@gmail.com
}

Received: May 16, 2016; Accepted: January 20, 2017; Available online: June 29, 2017; Printed: June 30, 2017

\begin{abstract}
A new species of Nessia is described from Sri Lanka. Nessia gansi $\mathrm{sp}$. $\mathrm{n}$. is distinguished from its sister species ( $N$. burtonii) based on the morphological and meristic data. The new species differs from all other congeners except $N$. burtonii Gray, by a combination of following characters: presence of four limbs; all limbs bearing three digits; interparietal broader than frontal. It distinguishes from $N$. burtonii by having five (vs. six) supraciliaries; one (vs. two) pretemporal/s; two (vs. one) primary temporal/s; three (vs. four) infralabials; 93-105 (vs. 110-124) paravertebral scale rows; 103114 (vs. 117-121) ventral scales; two (vs. three) subdigital lamellae under each digit of manus; mental as wide as postmental (vs. mental wider than postmental); and nostrils visible when viewed ventrally (vs. not visible). Two closely related species show a discrete distribution in Sri Lanka: N. gansi sp. n. is recorded from Kanneliya, Rumaswala, Kottawa, Panagula, Ambalangoda and Imaduwa in the first and second peneplains $(\sim 100 \mathrm{~m})$, whereas $N$. burtonii records (here corrected) are reported from Alagalla, Ambagamuwa, Gampola, Hiniduma and Kandy within the third peneplain (from $~ 500 \mathrm{~m}$ ). The identity of N. burtonii is stabilized through the designation of a neotype, and here it is re-described.
\end{abstract}

Key words: Central Hills, new species, peneplain, scincid lizards, snake-skink.

\section{INTRODUCTION}

Taxonomy of semi-fossorial snake-skinks in the genus Nessia Gray are poorly known in Sri Lanka. For the time being, in Sri Lanka, the genus is known through eight species: $N$. bipes Smith, $N$. burtonii Gray, N. deraniyagalae Taylor, $N$. didactyla (Deraniyagala), N. hikanala (Deraniyagala), N. layardi Kelaart, N. monodactyla (Gray) and N. sarasinorum (Müller). Species of the genus Nessia distributed in all climaticphysiographic zones, i.e., lowland wet zone, central hills, dry zone, knuckles range and semi-arid zone (Deraniyagala, 1931, 1940, 1953, 1954, 1964; Taylor, 1950; Gans, 1995; Somaweera \& Somaweera, 2009).

After the classic papers on the genus Nessia by Deraniyagala (1934, 1940, 1953, 1954, 1964) and Taylor (1950), no significant contribution has been made to assess their taxonomy. Gans (1995) collected ample specimens of skinks including Nessia from Sri Lanka during his visits to Sri Lanka to fulfil his passion of collecting Uropeltid snakes. His collections (skinks) are now lodged in various museums around the world and indeed brought forth several new species (e.g., Greer, 1991) and obviously valuable for the future studies.

Although several new species of skinks described from Sri Lanka (Greer, 1991; Wickramasinghe et al., 2007; Batuwita \& Pethiyagoda, 2007; Das et al., 2008), 
the lack of studies on evaluation of the data deficient species (IUCN, 2007). However, Batuwita and Pethiyagoda (2007) rediscovered and clarified the taxonomy of a data deficient species, 'Sphenomorphus' dorsicatenatus Deraniyagala, by giving a new combination as Lankascincus dorsicatenatus, and also Das et al. (2008) provided evidence for paraphyly of 'Eutropis macularia'. Meanwhile, Karunarathna et al. (2008) recorded Chalcides cf. ocellatus from Western Province of Sri Lanka. This record appeared to be due to the pet trade because it was re-identified as C. ocellatus (see Lavin \& Papenfuss, 2012). Somaweera \& Somaweera (2009) also provided an overview of Scincidae of Sri Lanka. Recently, Amarasinghe et al. (2016a, b) redescribed the Eutropis beddomei (Jerdon) and E. bibronii (Gray), and they removed E. bibronii from Sri Lankan skink list. Batuwita (2016) resolved the paraphyly of 'Eutropis macularia', update the taxonomy of Eutropis Fitzinger of Sri Lanka by providing a key to all the congeners and confirmed the previous records of Eutropis bibronii from Sri Lanka.

During museum reference work, we discovered a distinct species of Nessia in the collections of the National Museum Sri Lanka and the Wildlife Heritage Trust of Sri Lanka. This new species was previously confused with Nessia burtonii. The purpose of this account is to describe the new species found in the on-going study of review of scincid lizards of Sri Lanka.

\section{MATERIALS AND METHODS}

Scalation definitions follow Andreone \& Greer (2002); mensural data were taken with the aid of a dial Vernier caliper to the nearest $0.1 \mathrm{~mm}$, following the methods described by Batuwita \& Pethiyagoda (2007). Comparisons were made with preserved material in the collections of the National Museum of Sri Lanka, Colombo (NMSL), and the Wildlife Heritage Trust of Sri Lanka (WHT) now in NMSL. Additional sources of information include Deraniyagala $(1934,1940,1953,1954,1964)$ and Taylor (1950). Altitudes are given in metres above mean sea level; geographic coordinates were taken using topographic maps (1 inch: 1 mile, Survey Department, Colombo).

\section{RESULTS}

Nessia gansi sp. n.

(Figs 1-3, tab. 1)

Material examined. Holotype: NMSL WHT 7585 (adult male), $60.0 \mathrm{~mm}$ SVL, Mount Rumaswala, near Galle, $06^{\circ} 01^{\prime} \mathrm{N}, 80^{\circ} 14^{\prime} \mathrm{E}, \sim 10 \mathrm{~m}$ (elevation). Paratypes: NMSL WHT 2018, (1 male), $62.0 \mathrm{~mm}$ SVL, Panagula, 06을' $\mathrm{N}, 80^{\circ} 23^{\prime} \mathrm{E}, 60 \mathrm{~m}$; NMSL WHT 2329 (1 sub-adult female), $42.0 \mathrm{~mm}$ SVL, Richmond Hill, Galle, $06^{\circ} 03^{\prime} \mathrm{N}, 80^{\circ} 12^{\prime} \mathrm{E}$; 15 m; NMSL WHT 7649 (1 female), 67.0 mm SVL, Imaduwa, 06º $02^{`} \mathrm{~N}, 80^{\circ} 23^{\prime} \mathrm{E}, 60$ m; NMSL WHT 7650 (1 male) 68.0 mm SVL, Kanneliya Forest Reserve, Udugama, $06^{\circ} 25^{\prime} \mathrm{N}, 80^{\circ} 27^{\prime} \mathrm{E}, 150 \mathrm{~m}$; NMSL WHT 7651, (1 male), $64.0 \mathrm{~mm} \mathrm{SVL}$, same location data as above; NMSL WHT 7652, (1 male), $65.0 \mathrm{~mm} \mathrm{SVL}$, Ambalangoda, 0602'N, $80^{\circ} 23^{\prime} \mathrm{E}, 20 \mathrm{~m}$.

\section{Comparative material examined.}

Chalcidoseps thwaitesii: NMSL uncatalogued, Sri Lanka, $53.0 \mathrm{~mm}$ SVL.

Nessia bipes: NMSL WHT 9448, Corbett's Gap, Knuckles Range, $07^{\circ} 22^{\prime} \mathrm{N}$, 8051'E, $1000 \mathrm{~m}, 68.0 \mathrm{~mm}$ SVL. 


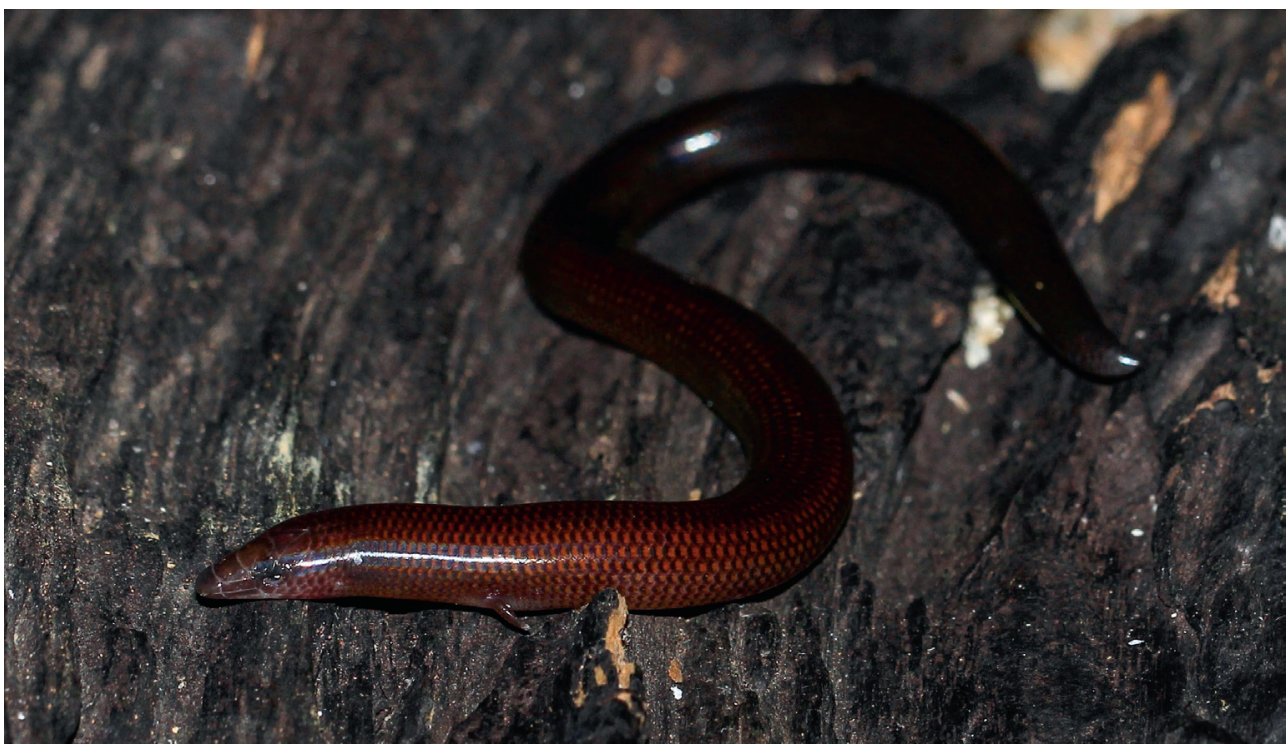

Fig. 1 - Nessia gansi sp. n., not preserved, from Atweltota in the Lowland wet zone (Photo courtesy: D. M. S. S. Karunarathna).

Nessia burtonii: NMSL WHT 7648, Sinharaja Forest reserve, 06²2’N, 80²8'E, $550 \mathrm{~m}, 71.5 \mathrm{~mm}$ SVL.

Nessia didactyla: NMSL uncatalogued, no locality, $82.0 \mathrm{~mm}$ SL (probably from type series).

Nessia monodactyla: NMSL WHT 2330, 7653-7655, Gannoruwa forest, 07'17'N, 80³6'E, 700 m, 74.0-82.0 mm SVL.

Nessia sarasinorum: NMSL WHT 1627 (2 examples), Wasgamuwa National Park, 07²3’N, 8059'E, 60 m, 56.0, 92.0 mm SVL.

\section{Diagnosis.}

Nessia gansi sp. n. differs from all other congeners except $N$. burtonii, by the combination of the following characters: presence of four limbs (vs. no limbs in $N$. deraniyagalae, $N$. hikanala and $N$. layardi; in having two hind-limbs in $N$. bipes, $N$. sarasinorum); three digits in each forelimb and hind-limb (vs. no digits in each forelimb and hind-limb in N. monodactyla, two digits in each forelimb and hind-limb in $N$. didactyla); interparietal broader than frontal (vs. interparietal narrower than frontal in N. sarasinorum). It distinguishes from Nessia burtonii by having five (vs. six) supraciliaries; one (vs. two) pretemporal/s; two (vs. one) primary temporal/s; three (vs. four) infralabials; 93-105 (vs. 110-124) paravertebral scale rows; 103-114 (vs. 117-121) ventral scales; two (vs. three) subdigital lamellae under each digit of menus; mental as wide as postmental (vs. mental wider than postmental), and nostrils visible when viewed ventrally (vs. not visible). Nessia gansi sp. n. is distinguished from Chalcidoseps thwaitesii (Günther) by having three digits in each forelimb and in hind-limb (vs. four digits in each forelimb and hind-limb), first pair of chin shields separated medially by a single scale (vs. in contact medially) and interparietal broader than frontal (vs. interparietal narrower than frontal). 


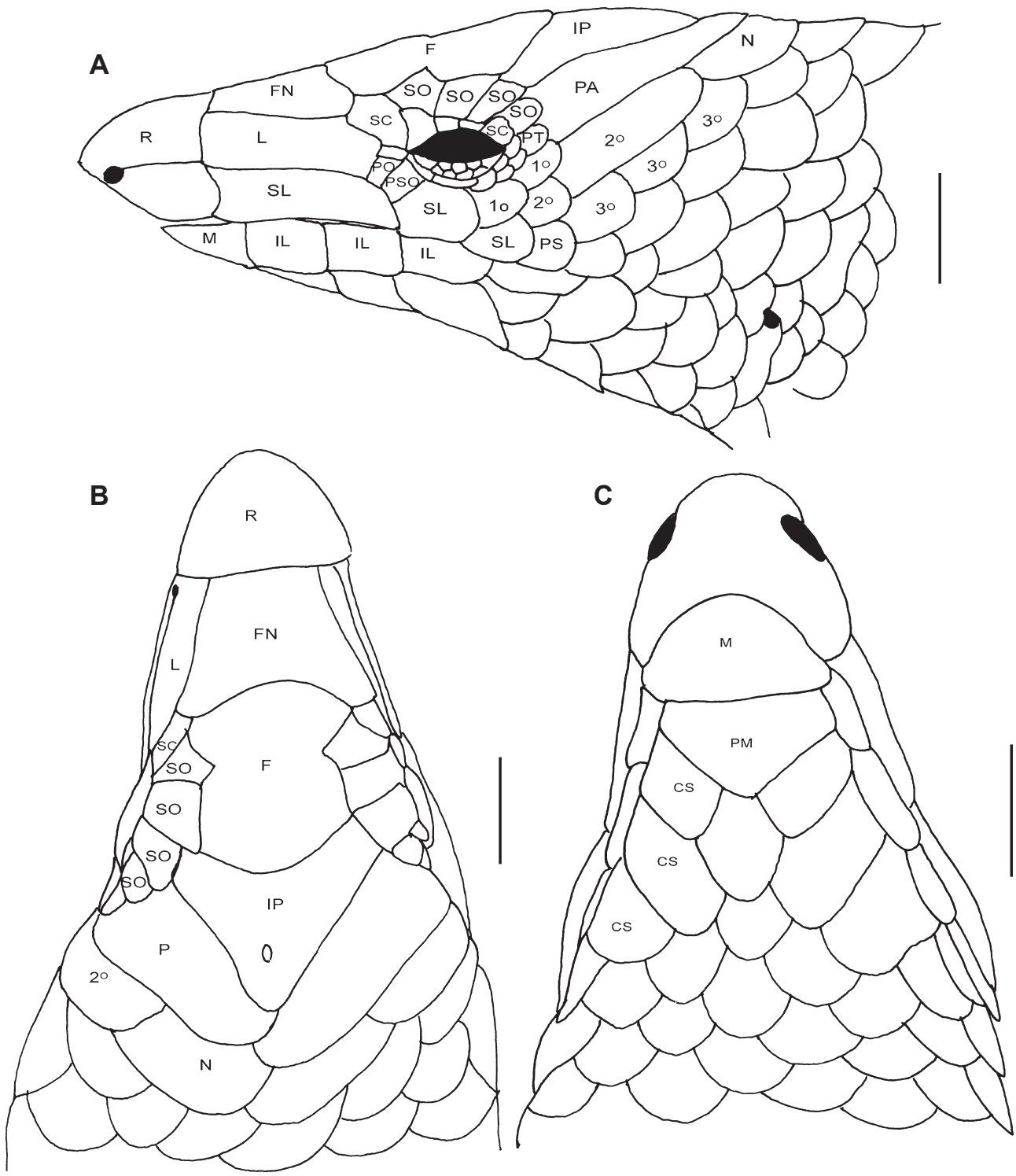

Fig. 2 - Nessia gansi sp. n. (holotype, adult male, NMSL WHT 7585): A, head lateral view; B, dorsal view; C, ventral view (Scale bars: $1 \mathrm{~mm}$ ). (R, rostral; FN, frontonasal; F, frontal; IP, interparietal; P, parietal; N, nuchal; L, loreal; SL, supralabials; PS, postsupralabial; SC, supraciliaries; SO, supraoculars; PO, preocular; PSO, postsubocular; PT, pretemporal; $1^{\circ}$, primary temporals; $2^{\circ}$, secondary temporals; $3^{\circ}$, tertiary temporals; IL, infralabials; M, mental; PM, postmental; CS, chin shields).

Description (data for the paratypes given in brackets; for measurements, see table 1).

Maximum snout-vent length (SVL) 60.0[42.0-67.0] mm; head relatively short (length $10.5[9.5-11.7] \%$ of SVL); snout acutely pointed; rostral about one third as long 


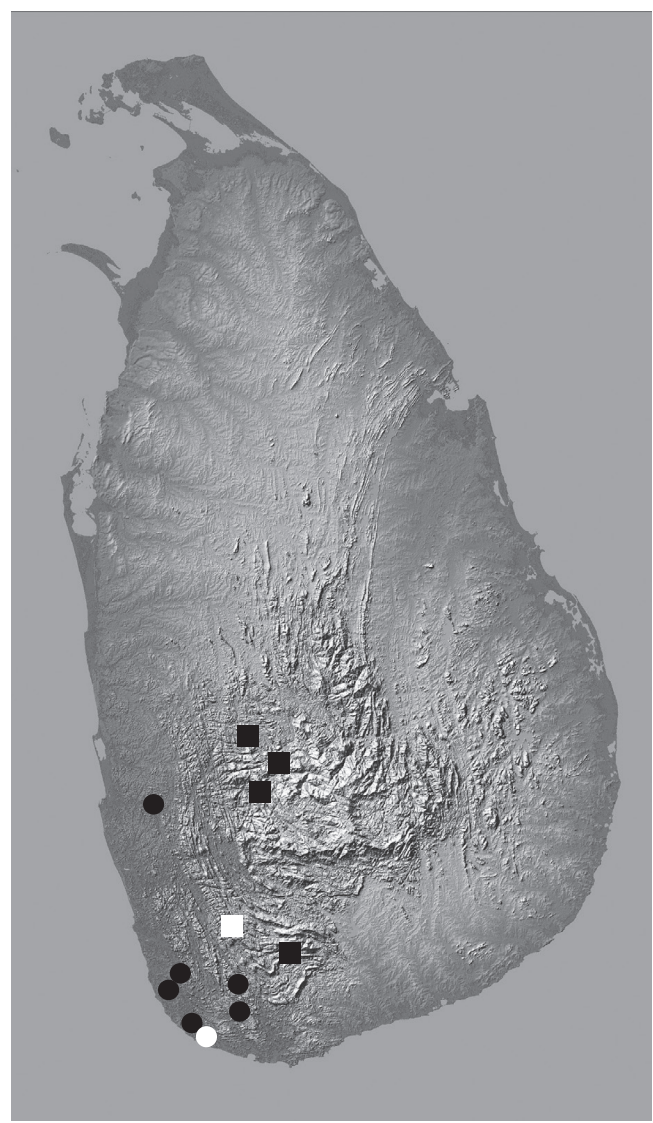

Fig. 3 - Records of Nessia gansi sp. n. (circles, open circle- holotype locality) and Nessia burtonii (squares, open square- neotype locality) in Sri Lanka.

as snout length; loreal as long as first supralabial; frontonasal longer than wide; frontal longer than wide, medially notched on each side by first supraocular; supraoculars four, first and second in contact with frontal; interparietal present, as wide as frontal; frontoparietal absent; parietals completely separated by interparietal; nuchals one pair; eye relatively small (eye diameter $12.7[9.7-14.8] \%$ of head length); two primary temporals in both sides; six supraciliaries in both sides, first supraciliary distinctly enlarged; one pretemporal in each side, in contact with parietal; two secondary temporals in each side, in contact each other, the upper longer than the lower; three supralabials in both sides, second in subocular position; one postsupralabial in each side; external ear opening rudimentary; nostrils visible when viewed ventrally; mental wider than long; mental as wide as postmental; postmental wider than long, in contact with first infralabial; three infralabials in each side; three pairs of enlarged chin shields, first two pairs separated medially by a single median scale and the third pair separated medially by three scales; enlarged chin shield scales laterally in contact with infralabial row; body relatively long (trunk length 75.8[72.6-79.7]\% of SVL); scales cycloid, striae on ventral scales; paravertebral scales 103[93-104]; 
$\frac{\frac{0}{3}}{\frac{\pi}{8}}$

\begin{tabular}{|c|c|c|c|c|c|c|c|c|c|c|c|c|c|}
\hline కే & 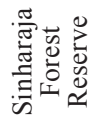 & 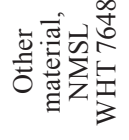 & $\stackrel{2}{a}$ & $\vec{\beth}$ & $\stackrel{\varrho}{ }$ & $\stackrel{n}{n}$ & 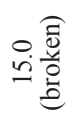 & $\stackrel{0}{\bullet}$ & $\stackrel{n}{m}$ & $\begin{array}{l}\infty \\
\dot{0}\end{array}$ & $\ddot{\circ}$ & $\tilde{n}$ & $\ddot{n}$ \\
\hline$\ddot{z}$ & 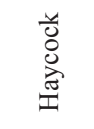 & 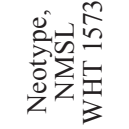 & $\stackrel{\sim}{\sim}$ & $\Xi$ & $\stackrel{ \pm}{\simeq}$ & $\stackrel{0}{i}$ & 율 & $\stackrel{\circ}{i}$ & $\stackrel{\infty}{i}$ & ఫֶ. & $\stackrel{\circ}{-}$ & $\tilde{\sim}$ & $\ddot{n}$ \\
\hline \multirow{7}{*}{ 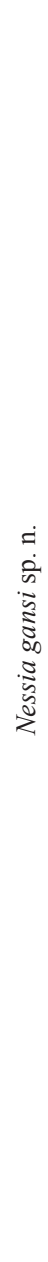 } & 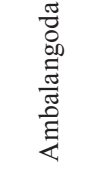 & 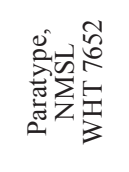 & $\stackrel{\sim}{\sim}$ & $\stackrel{2}{0}$ & ฮิ & î. & 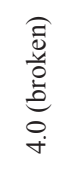 & $\stackrel{\circ}{i n}$ & $\stackrel{\infty}{i}$ & గु & $\stackrel{0}{\circ}$ & $\tilde{\sim}$ & $\stackrel{\circ}{\dot{m}}$ \\
\hline & 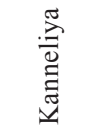 & 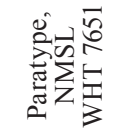 & त & $\stackrel{\varrho}{ }$ & $\stackrel{\varrho}{\varrho}$ & $\stackrel{\circ}{+}$ & $\stackrel{\circ}{\dot{q}}$ & $\stackrel{\circ}{\vec{n}}$ & $\stackrel{\circ}{\dot{m}}$ & $\stackrel{\nabla}{6}$ & $\stackrel{\infty}{\circ}$ & $\ddot{n}$ & $\stackrel{\circ}{+}$ \\
\hline & 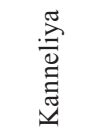 & 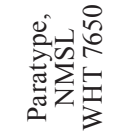 & $\approx$ & $\stackrel{\Xi}{\Xi}$ & $\stackrel{\curvearrowleft}{\varrho}$ & $\stackrel{0}{\infty}$ & 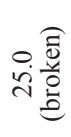 & i̊ & $\stackrel{\circ}{\dot{m}}$ & $\overrightarrow{6}$ & oे & $\stackrel{\circ}{i}$ & $\stackrel{+}{+}$ \\
\hline & 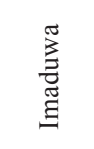 & 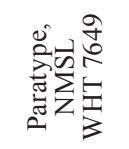 & $\stackrel{\sim}{\sim}$ & $\hat{\sigma}$ & $\hat{\sigma}$ & $\frac{0}{\dot{b}}$ & 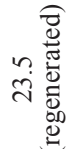 & î & $\stackrel{+}{r}$ & $\stackrel{\infty}{0}$ & $\stackrel{\circ}{-}$ & $\stackrel{\circ}{\dot{m}}$ & $\stackrel{\circ}{+}$ \\
\hline & 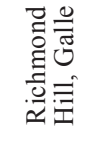 & 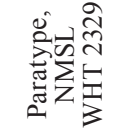 & $\stackrel{\nabla}{\sim}$ & $\hat{\sigma}$ & $\kappa$ & 犬ి & 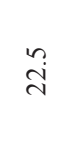 & $\frac{n}{n}$ & $\tilde{n}$ & $\stackrel{\vartheta}{+}$ & $\tilde{0}$ & $\stackrel{\circ}{i}$ & $\stackrel{\circ}{\dot{m}}$ \\
\hline & 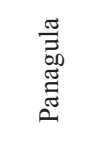 & 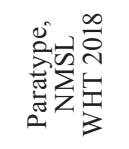 & $\sqrt{2}$ & $\stackrel{2}{0}$ & $\stackrel{ \pm}{\varrho}$ & तु & 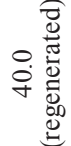 & $\stackrel{\circ}{\dot{y}}$ & $\hat{i}$ & ชู & $\stackrel{\infty}{0}$ & $\stackrel{\circ}{i}$ & $n$ \\
\hline & 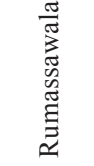 & 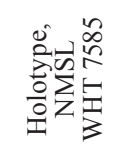 & $\approx$ & $\stackrel{\infty}{\varrho}$ & $\tilde{\varrho}$ & 8 & in & $\ddot{q}$ & $\vec{i}$ & भु? & $\stackrel{\infty}{\circ}$ & $\tilde{n}$ & $\stackrel{\leftrightarrow}{+}$ \\
\hline & 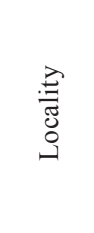 & 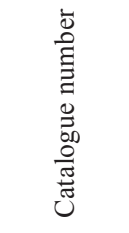 & $\begin{array}{l}\text { 吾 } \\
0 \\
0 \\
0 \\
2\end{array}$ & $\begin{array}{l}\frac{n}{\pi} \\
\frac{\pi}{0} \\
\frac{0}{D}\end{array}$ & 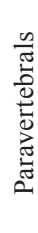 & $\stackrel{i}{i}$ & 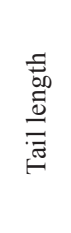 & 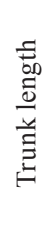 & 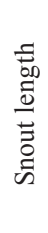 & 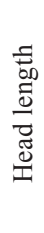 & 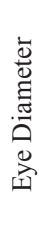 & 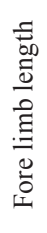 & 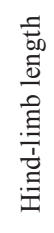 \\
\hline
\end{tabular}


ventral scales 108[103-114]; longitudinal scale rows at midbody 25[22-26]; SVL $60.0[42.0-68.0] \mathrm{mm}(n=7)$, SVL 9.5[9.0-11.7] times in head length; un-regenerated tail length 35.0[22.5-40.0] mm (in 3 specimens, in NMSL WHT 2329, NMSL WHT 7585, NMSL WHT 7651), un-regenerated tail length 0.6[0.5-0.6] times in SVL. Four limbs present, rudimentary, each limb tridactyl; three subdigital lamellae under each digit of manus and three subdigital lamellae under each digit of pes. Forelimb length as $\%$ of SVL $4.2[2.9-4.8] \%$ and hind-limb length as \% of SVL $6.7[4.6-7.1] \%$.

\section{Colouration.}

In live, general body colour dark brown, each dorsal scale with a distinct dark spot at posterior end; ventral side dusky brown. In preservative, body colour dark brown and ventral side light brown.

\section{Etymology.}

The species name is a patronym in the Latin genitive singular, in honour of Carl Gans (September 7, 1923 - November 30, 2009), for his enormous contributions to herpetology.

\section{Distribution and natural history.}

The new species is recorded from Atweltota (D. M. S. S. Karunarathna, pers. comm.), Kanneliya, Rumaswala, Kottawa, Panagula, Ambalangoda and Imaduwa within the first and second peneplains (see Wadia, 1945) of Sri Lanka. This species is found in loose soil, in leaf debris, close to rubbish heaps in home gardens. It prefers damp forests or home gardens (Fig. 3).

\section{Nessia burtonii Gray, 1839}

(Figs. 3-5, tab. 1)

Material examined. Neotype (here designated, ICZN (1999), Art. 75.3. and 75.3.1-4., 75.3.6.): WHT 1573, Haycock Mountain, near Hiniduma, $06^{\circ} 20^{\prime} \mathrm{N}, 8^{\circ} 18^{\prime} \mathrm{E}$, $\sim 660 \mathrm{~m}$ (elevation), $71.0 \mathrm{~mm}$ SVL.

Description of neotype (data for other recent material given in brackets; for measurements, see Tab. 1).

Maximum snout-vent length (SVL) 71.0[71.5] mm; head relatively short (head length $9.0[9.5] \%$ of SVL); snout obtusely pointed; rostral about little more than one third as long as snout length; loreal as long as first supralabial; frontonasal broader than long; frontal as long as wide, medially notched on each side by first supraocular; supraoculars four, first and second in contact with frontal; interparietal present, wider than frontal; frontoparietal absent; parietals completely separated by interparietal; nuchals one pair; eye relatively small (eye diameter $15.6[10.3] \%$ of head length); single primary temporal in both sides; five supraciliaries in both sides, first supraciliary distinctly enlarged; two pretemporals in each side, in contact with parietal; two secondary temporals in each side, in contact each other, the upper longer than the lower; four supralabials in both sides, second in subocular position; one postsupralabial in each side; external ear opening rudimentary; nostrils laterally oriented; mental wider than long; mental little broader than postmental; postmental wider than long, in contact with first infralabial; three infralabials in each side; three pairs of enlarged chin shields, first two pairs separated medially by a single median 


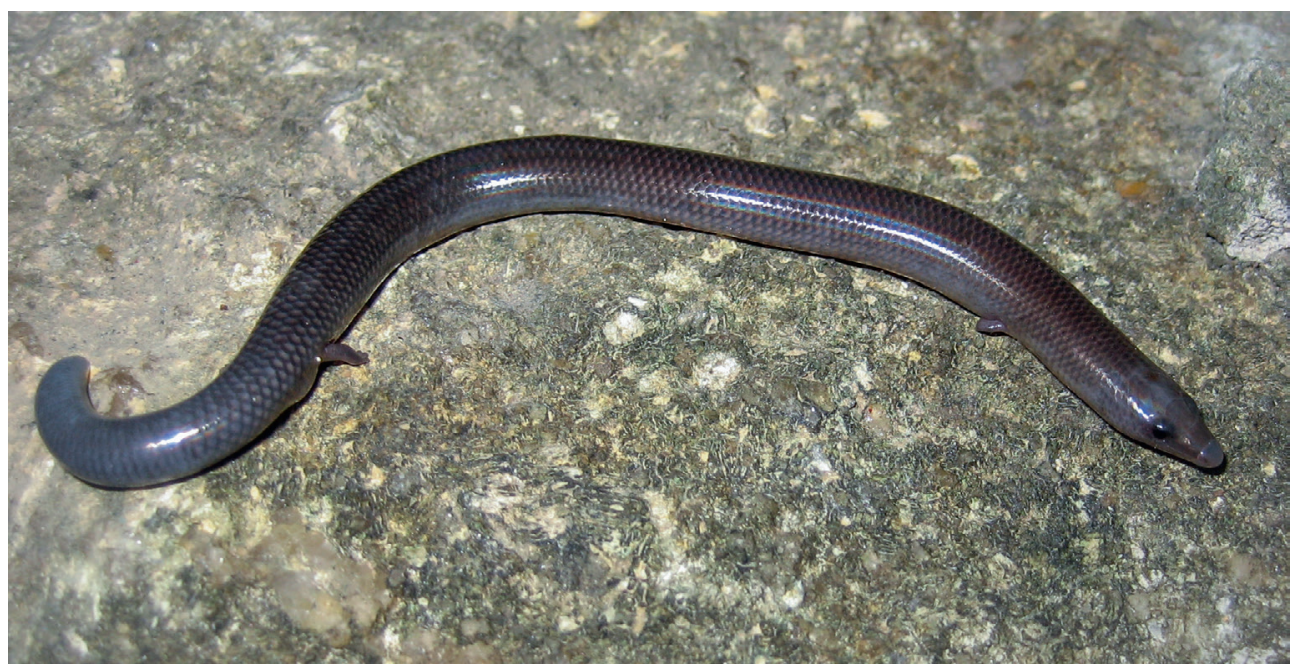

Fig. 4 - Nessia burtonii, NMSL WHT 7648, from Sinharaja Forest reserve.

scale and third pair separated medially by three scales; enlarged chin shield scales laterally in contact with infralabial row; body relatively long (trunk length 76.1[78.3]\% of SVL); scales cycloid, striae on ventral scales; paravertebral scales 124[110]; ventral scales 117[121]; longitudinal scale rows at midbody 26[25]; SVL 71.0[71.5] mm, SVL 11.1[10.5] times in head length; tail broken 20.0 [15.0 mm]. Four limbs present, rudimentary, each limb tridactyl; two subdigital lamellae under each digit of manus and three subdigital lamellae under each digit of pes. Forelimb length as a $\%$ of SVL $3.5 \%$ (in two specimens) and hind-limb length as \% of SVL $4.9 \%$ (in two specimens).

\section{Colouration.}

In live, general body colour is olive brown or light brown, each scale with a distinct dark spot at posterior end; ventral side dusky brown. In preservative, body colour dark brown and ventral side light brown.

Etymology.

Gray (1839) named Nessia burtonii in honour of Major Edward Burton of the Museum of Chatham (1790-1867) (Beolens et al., 2011). Etymology of Nessia burtonii as mentioned by Batuwita \& Edirisinghe (2015) is incorrect.

\section{Distribution.}

Nessia burtonii is recorded from Alagalla, Ambagamuwa, Gampola, Hiniduma, Kandy and Sinharaja World Heritage Site (Fig. 3).

\section{DISCUSSION}

Gray (1839) described Nessia burtonii from Sri Lanka, but without a specific locality ('Ceylon'). His description limiting the true identity of $N$. burtonii because the characters given by Gray (op. cit.) are common to the new species and to Nessia burtonii. Hence, we look for the subsequent records of Nessia burtonii in the 19th century. However, all but Kelaart's (1852) records had no specific locality (i.e., Ceylon) 


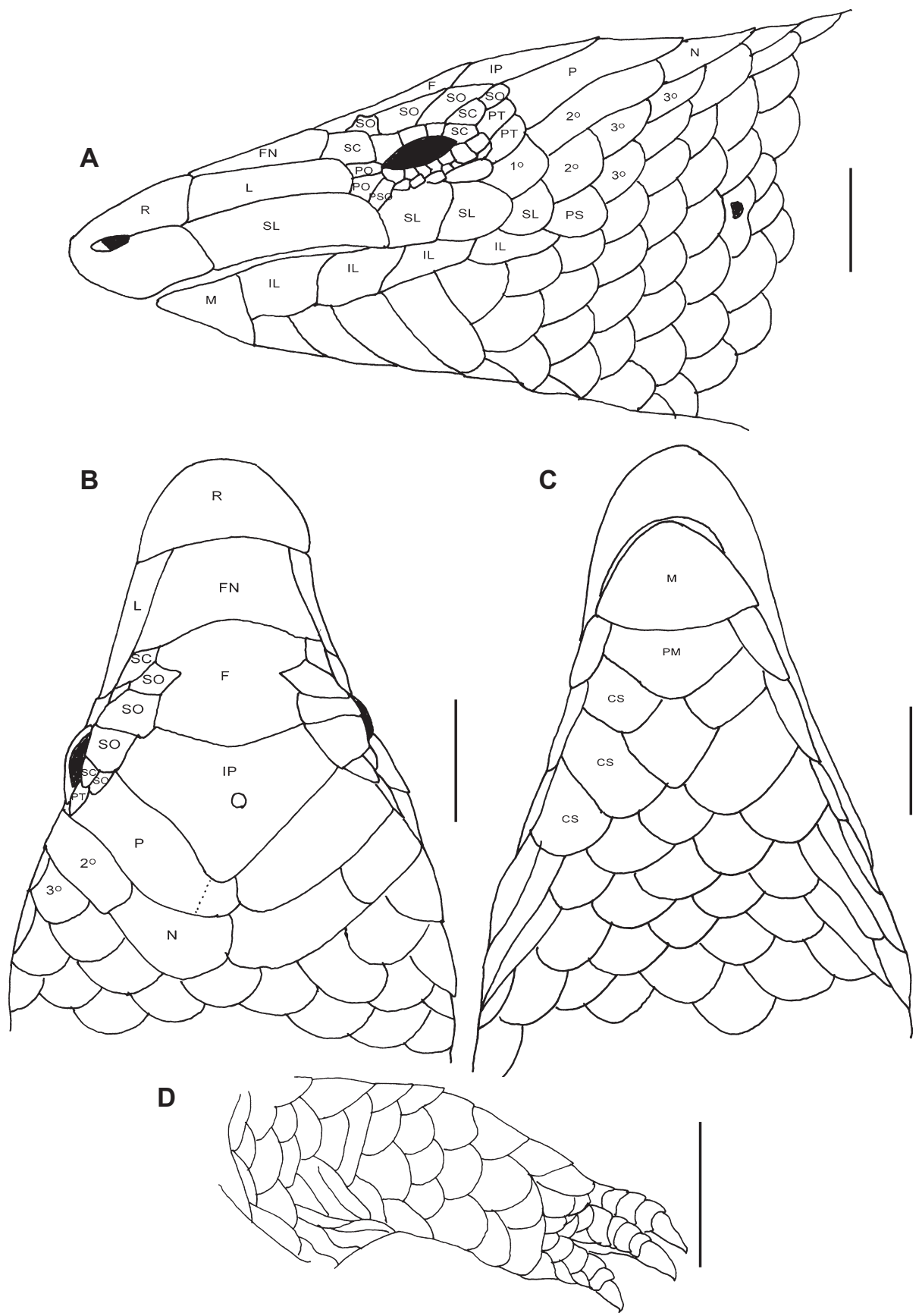

Fig. 5 - Nessia burtonii (neotype, WHT 1573): A, head lateral view; B, dorsal view; C, ventral view (Scale bars: $1 \mathrm{~mm}$ ) and D, left manus (Scale bar: $1 \mathrm{~mm}$ ). (R, rostral; FN, frontonasal; F, frontal; IP, interparietal; P, parietal; N, nuchal; L, loreal; SL, supralabials; PS, postsupralabial; SC, supraciliaries; SO, supraoculars; PO, preoculars; PSO, postsubocular; PT, pretemporals; $1^{\circ}$, primary temporal; $2^{\circ}$, secondary temporals; $3^{\circ}$, tertiary temporals; IL, infralabials; M, mental; PM, postmental; CS, chin shields). 
(Günther, 1864; Boulenger, 1887). In addition, Günther (op. cit) and Boulenger (op. cit.) might have not seen the type/s of the Nessia burtonii (they had not stated the examined specimens as types). Kelaart (1852) reported that it was common at Ambagamuwa $\left(07^{\circ} 01^{\prime} \mathrm{N}, 80^{\circ} 29^{\prime} \mathrm{E}, \sim 760 \mathrm{~m}\right.$ elevation, within the third peneplain). Hence, being a common skink in the Central Hills in the mid-19th century, specimens referred to Nessia burtonii were obviously secured in the collections, in mid-1800s in Central Hills. Besides, the lizards which had been described in the mid-19th century were very unlikely to be made from the first and second peneplains (including the coastal belt) because almost all lizard species were known to be from remote inland locations (e.g., Chalcidoseps thwaitesii, Ceratophora stoddartii, C. tennentii, Cyrtodactylus fraenatus, Cyrtodactylus (Geckoella) triedrus, Calotes liocephalus etc., from the collections of E. H. Kelaart, G. H. K. Thwaites, W. Ferguson and R. H. Beddome). It is further supported by Kelaart's description of Nessia burtonii from Ambagamuwa

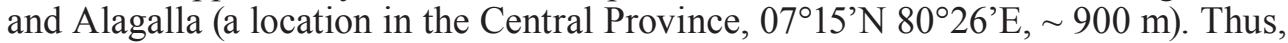
we are confident that Nessia burtonii was, in fact, collected from Central Hills ( $>$ $500 \mathrm{~m}$ elevation).

Given that its holotype is lost and there is no type locality (Smith, 1935; Uetz et al., 2016, P. Campbell, pers. comm., 25 July 2014), it is desirable that its identity be stabilized through the designation of a neotype. Subsequent specimens had been collected and assigned to Nessia burtonii (Kelaart, 1852; Günther, 1864, Boulenger, $1887)$ according to the neotype, we here designated from Haycock Mountain $(\sim 660 \mathrm{~m}$ a.s.1.): frontonasal as long as frontal, interparietal broader than frontal and frontal as broad as long. We therefore designate the $71.0 \mathrm{~mm}$ SVL specimen NMSL WHT 1573 as neotype of Nessia burtonii Gray, 1839. A description of the neotype is provided, above, which is consistent with the brief original description of this species and the descriptions provided by subsequent authors (Günther, 1864; Boulenger, 1887). The neotype is from Haycock Mountain ( $\sim 660 \mathrm{~m}$ a.s.l.), in the third peneplain (>500 m a.s.1.), which lies within the elevation, in which Nessia burtonii commonly occurs in the mid-19th century (see Kelaart, 1852).

Nessia gansi sp. n. and N. burtonii are discrete species based on their external morphology, meristic data and as well as in geography. They are geographically separate based on altitudinal difference of their habitats. Nessia burtonii collected from Haycock Mountain ( $\sim 660 \mathrm{~m}$ a.s.1.), whereas Nessia gansi sp. n. (holotype) collected from Rumaswala ( $\sim 10 \mathrm{~m})$ close to the sea. Likewise, Nessia sarasinorum and $N$. bipes show similar discrete geographic distribution in Sri Lanka. The two localities of the species are $\sim 50 \mathrm{~km}$ straight-line distance: $N$. sarasinorum recorded from Dambulla (Inamaluwa, $07^{\circ} 56^{\prime} \mathrm{N}, 80^{\circ} 41^{\prime} \mathrm{E}, \sim 100 \mathrm{~m}$ ) and $N$. bipes distributed in the Knuckles Range (Corbett's Gap, $07^{\circ} 22^{\prime} \mathrm{N}, 80^{\circ} 51^{\prime} \mathrm{E}, \sim 900 \mathrm{~m}$ ). The altitudinal difference and geographical barriers (i.e., an example of vicariance) might have caused allopatric speciation of these small semi-fossorial vertebrates.

The present study is part of a review series of the scincid lizard individuals of Sri Lanka (Lankascincus: Batuwita \& Pethiyagoda, 2007; Eutropis: Batuwita, 2016). These, together with Greer (1991) and Das et al., (2008) have helped to highlight a high degree of cryptic diversity within the various genera. Recently, Miralles et al. $(2011,2016)$ showed that reduction of number of scales on the anteriomost part of the head might have contributed to high species diversity in fossorial skinks. They also recognized convergent evolution of Nessia of Sri Lanka with three other Scincidae genera and another single genus of family Dibamidae. 
We here conclude the type/s of Nessia burtonii had not been collected from the lowland wet zone area of Sri Lanka (first and second peneplains) where the N. gansi sp. n. inhabits. Thus, we here re-define the previous records of three-toed Nessia from lowland areas of Sri Lanka which, in fact, belongs to Nessia gansi sp. n. Moreover, within the same climatic-physiographic zone (i.e., Lowland wet zone, Central Hills, Knuckles Range, Dry zone and Semi-arid zone), in the same peneplain, the same species of Nessia may harbour, although the localities are well distant from each other (see also Deraniyagala, 1964; Gans, 1995).

\section{ACKNOWLEDGEMENTS}

This work was partially supported by the Nagao Natural Environment Foundation (NEF), Japan and the Postgraduate Institute of Agriculture of Sri Lanka (PGIA). We are grateful to R. Pethiyagoda (WHT) for giving us access to the collection. We thank S. Kasthuriarachchi, L. Somaratne, M. Goonatilake and C. Munasinghe (all of NMSL) for permission to access material in their care. SB is also grateful to D. M. S. S. Karunarathna (Nature Exploration \& Education Team) for providing fig. 1; Jeffery De Lile (Tongji University, China), Judah Mantu (PNG Forest Authority, Papua New Guinea) and Huang Kairu (Nanjing Forestry University, China) for their assistance in preparation of the manuscript. Finally, we thank Costica Adam ('Grigore Antipa' National Museum of Natural History, Bucharest) and Aurélien Miralles (French National Centre for Scientifc Research, Paris) for criticism and helpful suggestions that helped substantially to improve the quality of this manuscript.

\section{REFERENCES}

AMARASINGHE, A. A. T., P. D. CAMPBELL, S. R. CHANDRAMOULI, K. DEUTI, S. RAHA, D. M. S. S. KARUNARATHNA, I. INEICH (2016a) Taxonomy and natural history of Eutropis beddomei (Jerdon, 1870) (Reptilia: Scincidae), including a redescription of the holotype. Zootaxa, 4132(4): 509-520.

AMARASINGHE, A. A. T., P. D. CAMPBELL, S. R. CHANDRAMOULI, K. DEUTI, S. RAHA, D. M. S. S. KARUNARATHNA, I. INEICH (2016b) Taxonomy of two endemic Indian skinks, Eutropis bibronii (Gray, 1838) and E. nagarjunensis (Sharma, 1969) (Reptilia: Scincidae), including redescriptions of their types. Zootaxa, 4154(2): 155-168.

ANDREONE, F., A. E. GREER (2002) Malagasy scincid lizards: descriptions of nine new species, with notes on the morphology, reproduction and taxonomy of some previously described species (Reptilia: Squamata: Scincidae). Journal of Zoology, London, 258: 139-181.

BATUWITA, S. (2016) Description of two new species of Eutropis (Reptilia: Scincidae) from Sri Lanka with a redescription of Eutropis madaraszi (Méhely). Journal of Herpetology, 50(3): 486-496.

BATUWITA S., U. EDIRISINGHE (2015) Nessia gansi: a second three-toed snake-skink (Scincidae) from Sri Lanka. International Zoological Congress of "Grigore Antipa", 18-21 November 2015, National Museum of Natural History, Bucharest, Romania, 138 pp.

BATUWITA S., R. PETHIYAGODA (2007) Description of a new species of Sri Lankan litter skink (Squamata: Scincidae). Ceylon Journal of Science (Biological Sciences), 36: 80-87.

BEOLENS, B., M. WATKINS, M. GRAYSON (2011) The Eponym Dictionary of Reptiles. The John Hopkins University Press, Baltimore, $312 \mathrm{pp}$.

BOUlENGER, G. A. (1887) Catalogue of the lizards in the British Museum (Natural History), 3, Lacertidae, Gerrhosauridae, Scincidae, Anelytropsidae, Dibamidae, Chamaeleontidae. London, $575 \mathrm{pp}$.

DAS, I, A. DE SILVA, C. C. AUSTIN (2008) A new species of Eutropis (Squamata: Scincidae) from Sri Lanka. Zootaxa, 1700: 35-52.

DERANIYAGALA, P. E. P. (1931) Some Ceylon lizards. Ceylon Journal of Science (Biological Sciences), 16(2): 139-180.

DERANIYAGALA, P. E. P. (1934) Some new fossorial skinks of Ceylon. Ceylon Journal of Science (Biological Sciences), 18: 231-233.

DERANIYAGALA, P. E. P. (1940) A new apodal lizard, Nessia hikanala from Ceylon. Proceedings of the Linnaean Society of London, 152(1): 37-39.

DERANIYAGALA, P. E. P. (1953) A Colored Atlas of Some Vertebrates from Ceylon. Tetrapod Reptilia, Volume 2, National Museum, Colombo. $101 \mathrm{pp}$.

DERANIYAGALA, P. E. P. (1954) The limbless lizards of Ceylon. Journal of the Royal Asiatic Society, Ceylon, New series, Part 1: 25-26. 
DERANIYAGALA, P. E. P. (1964) Some aspects of the fauna of Ceylon. Journal of the Royal Asiatic Society, Ceylon, New series 9, Part 2: 165-219.

GANS, C. (1995) New records of skinks from Sri Lanka. Lyriocephalus, 2: 21-24.

GRAY, J. E. (1839 [1838]) Catalogue of the slender-tongued saurians, with descriptions of many new genera and species. Annals and Magazine of Natural History, (1) 2: 331-337 (287-293).

GREER, A. E. (1991) Lankascincus, a new genus of scincid lizards from Sri Lanka, with description of three new species. Journal of Herpetology, 25 (1): 59-64.

GÜNTHER, A. C. L. G.(1864) The Reptiles of British India. Arment Biological press, Landisville, PA, $452 \mathrm{pp}$.

KARUNARATHNA, D. M. S. S., L. J. M. WICKRAMASINGHE, V. A. P. SAMARAWICKRAMA, D. A. I. MUNINDRADASA (2008) The range extension of genus Chalcides Laurenti, 1768 (Reptilia: Scincidae) to Sri Lanka. Russian Journal of Herpetology, 15: 225-228.

KELAART, E. F. (1852) Prodromus faunae Zeylanicae, being contributions to the zoology of Ceylon. Dodsworth and Company, Colombo, $197+62 \mathrm{pp}$.

LAVIN, B. R., T. J. PAPENFUSS (2012) The phylogenetic position of Chalcides ocellatus (Squamata: Scincidae) from Yemen and Somalia. Zootaxa, 3221: 26-36.

MIRALLES, A., J. KÖHLER, D. R. VIEITES, F. GLAW, M. VENCES (2011) Hypotheses on rostral shield evolution in fossorial lizards derived from the phylogenetic position of a new species of Paracontias (Squamata, Scincidae). Organisms, Diversity \& Evolution, 11: 135-150.

MIRALLES, A., T. JONO, A. MORI, R. GANDOLA, J. ERENS, J. KÖHLER, F. GLAW, M. VENCES (2016) A new perspective on the reduction of cephalic scales in fossorial legless skinks (Squamata, Scincidae). Zoologica Scripta, 45: 380-393.

SOMAWEERA, R., N. SOMAWEERA (2009) Lizards of Sri Lanka: a colour guide with field keys. Chimaira, Germany, 303 pp.

SMITH, M. A. (1935) The fauna of British India, including Ceylon and Burma. Reptiles and Amphibia, Vol. II. Sauria. Taylor and Francis, London, $440 \mathrm{pp}$.

TALYOR, E. H. (1950) Ceylonese lizards of the family Scincidae. University of Kansas Science Bulletin, 33: 481-518.

UETZ, P., P. FREED, J. HOŠEK (2016) The Reptile Database, http://www.reptile-database.org (accessed on 16.10.2016).

WADIA, D. N. (1945) The three superimposed peneplains of Ceylon: their physiography and geological structure. Records of the Department of Mineralogy (Ceylon) 1: 25-32.

WICKRAMASINGHE, L. J. M., R. RODRIGO, N. DAYAWANSA, U. L. D. JAYANTHA (2007) Two new species of Lankascincus (Squamata: Scincidae) from Sripada Sanctuary (Peak Wilderness), in Sri Lanka. Zootaxa, 1612: 1-24.

*** ICZN [International Commission for Zoological Nomenclature] (1999) International Code of Zoological Nomenclature. International Trust for Zoological Nomenclature, London, $306 \mathrm{pp}$.

*** IUCN [International Union for Conservation of Nature] (2007) The 2007 Red List of Threatened Fauna and Flora of Sri Lanka. IUCN Sri Lanka and the Ministry of Environment and Natural Resources, Colombo, xiii +148 pp. 